\title{
Assessment of hydrological factors affecting shallow groundwater chemistry in the most urbanized area of the coastal sedimentary basin of Togo
}

\author{
Kossitse Venyo Akpataku ${ }^{1, a}$, Masamaeya D. T. Gnazou ${ }^{1}$, Yao Tse Agbefu Nomesi ${ }^{2}$, Phintè Nambo ${ }^{1}$, \\ Komi Doni $^{1}$, Limam Moctar Bawa ${ }^{1}$, and Gbandi Djaneye-Boundjou ${ }^{1}$ \\ ${ }^{1}$ Laboratory of Applied Hydrology and Environment, University of Lomé, Togo, BP 1515, Lomé, Togo \\ ${ }^{2}$ Agency of Water and Sanitation for Africa, Office of Togo, BP 3689, Lomé, Togo \\ a current address: Department of Chemistry, University of Kara, Togo, BP 404, Kara, Togo
}

Correspondence: Kossitse Venyo Akpataku (avenyo@gmail.com)

Published: 16 November 2021

\begin{abstract}
The project to reduce environmental and health risks related to the activity of boreholes water sellers in Lomé (in French PRRESAF) was implemented to contribute to the guarantee of public health. One of its objectives is to improve the hydrological understanding of the shallow Continental Terminal (CT) aquifer tapped by water sellers. It is a vital water resource in the coastal sedimentary extending from Ghana to Nigeria. The results presented here are part of this project and aim at assessing the hydrological factors controlling CT groundwater quality and chemistry using principal component analysis (PCA), hierarchical cluster analysis (HCA), and GIS. High-resolution sampling campaigns for major ions water quality analyses were performed to improve the accuracy of factors assessment. The results showed that groundwater is predominantly acidic with varying degrees of mineralization ranging from very soft to brackish waters. The integration of multivariate results to GIS allows classifying samples into five main groups. They revealed the probable recharge and discharge areas, associated hydrochemical evolution along flow paths, and areas under the high impact of land-use dynamics, wastewaters/sewage infiltration, and interactions with surface water systems. This study appears useful for managing boreholes' water sellers' activity relative to the integrity of groundwater resources and public health.
\end{abstract}

\section{Introduction}

The coastal town of Lomé is located on the sedimentary basin of the Gulf of Guinea, namely the Keta basin that extends from Ghana to Nigeria. Like in other African cities, there is a galloping growth of the population with a rate of $6.1 \%$ per year and a tremendous socio-economic development these last years (BCR/DGSN/MPRPDAT, 2011; MPTTogo, 2013). Unfortunately, sanitation and drinking water supply systems have not kept pace with the city's expansion. Septic tanks and sumps are not built according to the rules, and uncollected wastes become uncontrolled rubbish dumps. In general, domestic and industrial wastewaters are not treated before being released into the environment. Runoff from these environments is drained into natural storm basins, some developed as artificial storm pools and con- nected to the lagoon system (MPT-Togo, 2013; Ayah et al., 2015). All these features constitute potential sources of high contamination of the Continental Terminal shallow aquifer, the primary and overexploited resource for drinking water in Lomé (Alfa-Sika Mande et al., 2012; Gnazou et al., 2017). In addition to formal exploitation by the Togolese Water Company (TdE) which cannot cover the population's needs, the past decade has witnessed a proliferation of informal private boreholes. Despite regulatory texts, water's physicochemical or bacteriological quality is not usually insured before human consumption. In this context, the project for the reduction of environmental and health risks related to the activity of sellers of boreholes water in the city of Lomé (in French PRRESAF) was implemented in order to contribute to the guarantee of public health. One of its objectives is to improve the hydrological understanding of the shallow Conti- 
nental Terminal (CT) aquifer tapped by water sellers. As part of the project mentioned above, this study aims at assessing the relative importance of hydrological factors affecting the CT shallow groundwater chemistry. A multivariate statistical analysis approach integrated with a Geographical Information System (GIS) was applied to a dataset obtained from the physicochemical characterization of groundwater.

\section{Study area}

Lomé and its suburban areas lay between the latitudes $6^{\circ} 08^{\prime}$ and $6^{\circ} 18^{\prime} \mathrm{N}$ and the longitudes $1^{\circ} 5^{\prime}$ and $1^{\circ} 23^{\prime} \mathrm{E}$ (Fig. 1). It covers an area of around $360 \mathrm{~km}^{2}$ with 1.6 million inhabitants in 2010 (BCR/DGSCN/MPRPDAT, 2011).

The study area consists of the Plateau of Agoenyive (20 to 67 m a.s.l.) from the Central part toward the North, the narrow littoral cordon in the South, and the alluvial plain of Zio in the East with an altitude lower than $20 \mathrm{~m}$ a.s.l. The climate is subequatorial Guinean type, characterized by two rainy seasons (April to July and September to October) and two dry seasons (July to August and November to March) with an average rainfall of $900 \mathrm{~mm} /$ year. The drainage network is part of the lake Togo Basin in connection with the Zio River and the lagoon system of Lomé. The geological context of the study area integrates that of the post-Paleozoic sedimentary series of the Gulf of Guinea (Ghana-Togo-Benin-Nigeria) (Sylvain et al., 1986; Da Costa et al., 2013). The Geological north-south cross-section of Cretaceous-Quaternary sediments is presented in Fig. 1. The sedimentary basin counts four aquifers. They are linked to Quaternary formations, the sands of the Continental Terminal, the limestone and sand of the Palaeocene, and the sand and sandstone of the Maastrichtian (Gnazou et al., 2017). The Continental Terminal (CT) aquifer is the main one exploited by boreholes water sellers and private boreholes for domestic purposes. With an NW-SE groundwater flow direction, the average transmissivity of CT aquifer is around 5 to $8 \times 10^{-3} \mathrm{~m}^{2} / \mathrm{s}$ (Gnazou et al., 2017). The mean depth of informal water sellers boreholes is around $30 \mathrm{~m}$ below ground level (m b.g.l.). In the south and east parts, the CT aquifer is influenced by the Quaternary sediments aquifer, where the average depth of boreholes and wells is $10 \mathrm{~m}$ with a static level close to ground level.

\section{Methods}

Nighty six boreholes were monitored in 2015 and 2016 for physicochemical characterization. Parameters such as temperature, $\mathrm{pH}$, electrical conductivity, TDS, and dissolved oxygen are measured in situ using a portable multimeter (WTW, Instruments). Major and minor ions analyses were performed using the French Association of Standardization (AFNOR) methods (Rodier et al., 2009). Results are validated for ionic balance between $-10 \%$ and $+10 \%$. The factor analysis based on the Principal Components (PCA) and the hierarchical cluster analysis ACH based on the Ward aggregation method and the measurement of similarity by Euclidean distances are performed as described by Cloutier et al. (2008) using STATISTICA software. ArcGIS software was used for spatial analysis and holistic interpretations.

\section{Results and discussions}

The $\mathrm{pH}$ values ranged between 4 and 8 , with an average of $5.8 \pm 0.7$ indicating the predominance of acidic water types. The electrical conductivity values vary between 234 and $6250 \mu \mathrm{s} / \mathrm{cm}$, and the corresponding TDS values range from 180 to $4738 \mathrm{mg} / \mathrm{L}$ with averages of $1523 \pm 1132 \mu \mathrm{s} / \mathrm{cm}$ and $1150 \pm 863 \mathrm{mg} / \mathrm{L}$ respectively. No significant differences $(p>0.05)$ were observed between the concentrations of chemical species during sampling periods suggesting no significant short-term variation of groundwater chemistry during the two hydrological years. The Durov Diagram presented in Fig. 2a shows that most of the samples exhibit Na$\mathrm{Cl}$ water types.

The principal component analysis (PCA) allows extracting three (3) variables which explain $77 \%$ of the total variance in the dataset (Table 1). Factor 1 accounts for $45 \%$ of the total variance with high positive loadings (>0.7) in TDS, $\mathrm{Ca}^{2+}$, $\mathrm{Mg}^{2+}, \mathrm{Na}^{+}, \mathrm{Cl}^{-}$, and $\mathrm{SO}_{4}^{2}$. Since $\mathrm{Cl}^{-}$and $\mathrm{SO}_{4}^{2-}$ are ubiquitous in the saline hydro system (Appelo and Postma, 2005), Factor 1 is defined as salinity. The predominance of saline groundwater samples suggests that the conjunction of factors such as dissolution of salts originated from sea spray and marine aerosols deposition, seawater intrusion, evaporation, mixing with brackish water from storm pools, and the lagoon system, along with anthropogenic contamination. They exert substantial control over the overall mineralization of groundwater.

Factor 2 accounts for $20 \%$ of the total variance with high positive loadings in $\mathrm{Fe}_{\text {total }}, \mathrm{pH}$, and $\mathrm{HCO}_{3}^{-}$and a strong negative loading for the $\mathrm{NO}_{3}^{-}$. Iron concertation high as $4.4 \mathrm{mg} / \mathrm{L}$ was found in the lower Paleocene aquifer and correlated with turbidity, probably due to release from confining clay particles (Gnazou et al., 2011). In this study, concentrations high as $5 \mathrm{mg} / \mathrm{L}$ are found in the upper shallow $\mathrm{CT}$ aquifer. Their association with $\mathrm{pH}$ and $\mathrm{HCO}_{3}^{-}$suggests a reductive dissolution of iron oxides by organic matter in acidic water following the Reaction (1) (Appelo and Postma, 2005).

$\mathrm{CH}_{2} \mathrm{O}+4 \mathrm{FeOOH}+7 \mathrm{H}^{+} \rightarrow 4 \mathrm{Fe}^{2+}+\mathrm{HCO}_{3}^{-}+6 \mathrm{H}_{2} \mathrm{O}$

This reductive condition can explain the negative loading for $\mathrm{NO}_{3}^{-}$which exists under oxic conditions. Factor 2 is then defined as the redox factor. In general, reduction conditions become important with depth, but they depend on recharge regime and land-use change (Lee et al., 2008).

Factor 3 explains $12 \%$ of the variance with negative loadings in dissolved oxygen $\left(\mathrm{O}_{2}\right)$ and positive loadings in $\mathrm{pH}, \mathrm{HCO}_{3}^{-}, \mathrm{NH}_{4}^{+}$and $\mathrm{K}^{+}$, suggesting high consumption of dissolved oxygen through the oxidation of 


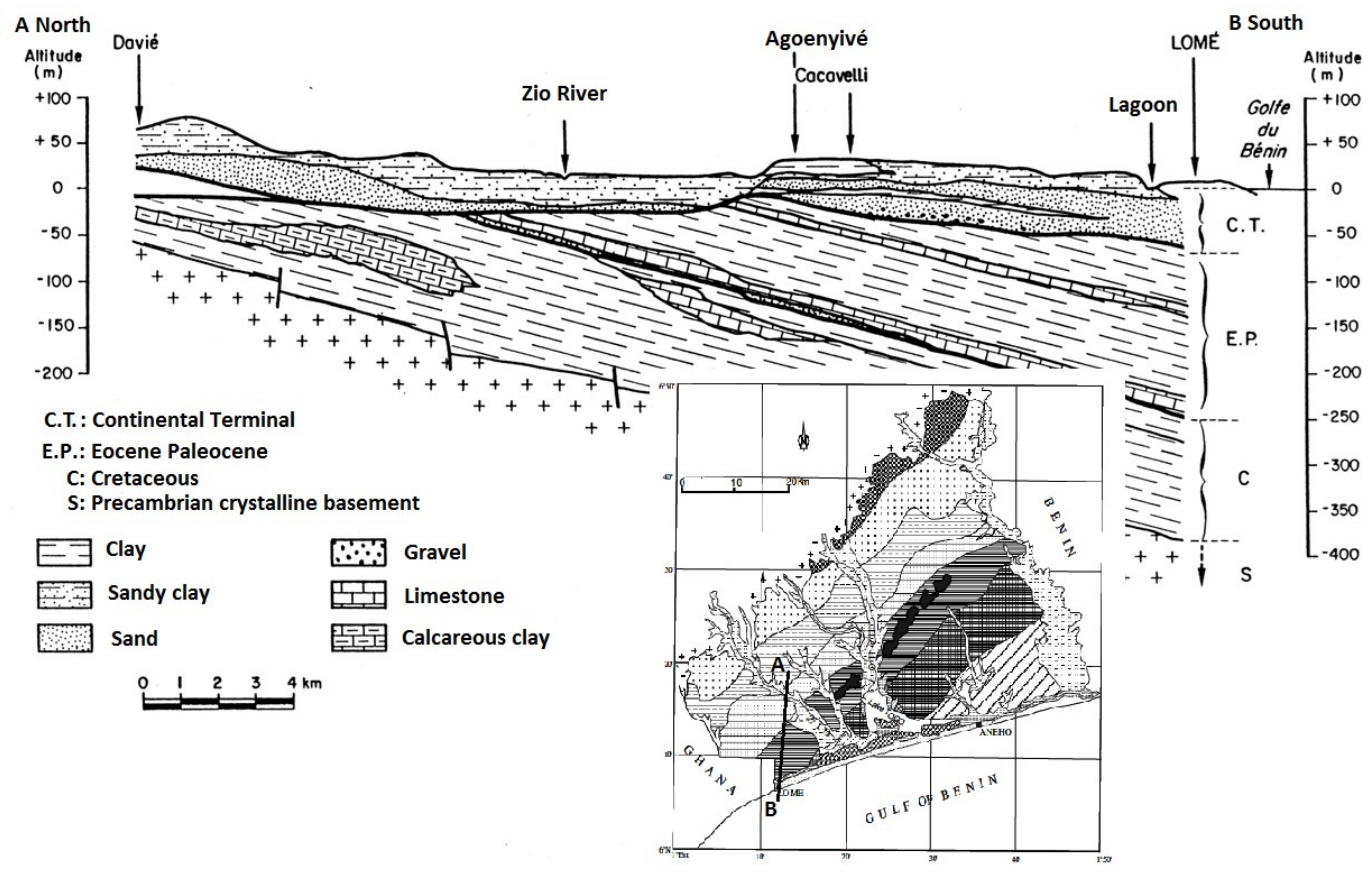

Figure 1. Geological north-south cross-section of Cretaceous-Quaternary sediments (modified after BRGM, 1982 and Sylvain et al., 1986; in Helstrup, 2006 and Gnazou et al., 2011).

Table 1. Results of the factor analysis. Bold values represent loadings $>0.7$.

\begin{tabular}{|c|c|c|c|c|c|c|c|c|c|c|c|c|c|c|c|c|}
\hline & $\mathrm{pH}$ & TDS & $\mathrm{Ca}^{2+}$ & $\mathrm{Mg}^{2+}$ & $\mathrm{Na}^{+}$ & $\mathrm{K}^{+}$ & $\mathrm{HCO}_{3}^{-}$ & $\mathrm{Cl}^{-}$ & $\mathrm{SO}_{4}^{2-}$ & $\mathrm{NO}_{3}^{-}$ & $\mathrm{Fe}_{\text {tot }}$ & $\mathrm{NH}_{4}^{+}$ & $\mathrm{O}_{2}$ & Eigenvalues & $\%$ variance & $\%$ cumul \\
\hline Factor 1 & 0.03 & 0.97 & 0.82 & 0.93 & 0.91 & 0.5 & 0.17 & 0.95 & 0.73 & 0.05 & -0.07 & 0.22 & -0.01 & 5.8 & 45 & 45 \\
\hline Factor 2 & 0.65 & -0.07 & 0.2 & 0.07 & -0.21 & 0.06 & 0.62 & -0.16 & 0.06 & -0.84 & 0.67 & -0.02 & 0.27 & 2.5 & 20 & 65 \\
\hline Factor 3 & 0.62 & 0.18 & 0.27 & 0.1 & 0.11 & 0.7 & 0.68 & -0.03 & 0.4 & 0.18 & -0.03 & 0.73 & -0.71 & 1.5 & 12 & 77 \\
\hline
\end{tabular}

anthropogenic organic matter. High $\mathrm{NH}_{4}^{+}$concentrations $(>30 \mathrm{mg} / \mathrm{L})$ are measured, indicating contamination from pit latrines, sewage, septic tank, and dumpsites as in other Sub-Saharan big cities where ammonium concentrations up to $60 \mathrm{mg} / \mathrm{L}$ were determined (Lapworth et al., 2017). Cation exchange could occur between $\mathrm{NH}_{4}^{+}$released in aqueous phases, and $\mathrm{K}^{+}$fixed on aquifer materials (Appelo and Postma, 2005). Therefore, Factor 3 is defined as indirect recharge from wastewaters.

The ACH allows distinguishing five (5) main samples groups which characteristics are presented in Fig. 2. Except for three boreholes (P56, P73, and P75), the remaining points maintained their membership in the $\mathrm{ACH}$ groups, irrespective of the sampling campaigns. The groups obtained can then strongly describe the spatial evolution of water chemistry. The graphical representation of the median chemical composition of groundwater in each group is presented through the Schoeller diagram (Fig. 3b). There is a gradual increase of TDS and ions contents following $\mathrm{G} 5<\mathrm{G} 3<\mathrm{G} 2<\mathrm{G} 4<\mathrm{G} 1$. The segments connecting major ions concentrations are quite parallel. The similar slope suggests similar geochemical processes, while the hydrochem- ical evolution along flow paths may explain the gradual increase of TDS. The spatial distribution pattern of groups (Fig. 2e) shows that the main direction from Group 5 to Group 1 corresponds to groundwater flow in the NW-SE direction. The segments connecting $\mathrm{NO}_{3}^{-}$, DO, and $\mathrm{NH}_{4}^{+}$are not parallel, suggesting that the impacts of anthropogenic contamination and land-use change on groundwater chemistry are not uniform in the study area. Group 5 samples (median TDS of $348 \mathrm{mg} / \mathrm{L}$ ) with very low factorial scores are located in the surrounding agriculture areas with isolated residences. These samples indicate zones where groundwater chemistry is controlled by a copious infiltration of rainwater, sea spray, and dissolution of surface salts. Groups 2, 3, and 4 samples represent part of the groundwater system under intermediate evolution along flow paths with gradual increase of salinity and variable degree of $\mathrm{NO}_{3}^{-}$contamination. Compared to Group 5, Group 2 samples are highly influenced by anthropogenic contamination due to increased population density (Fig. 2e). Group 4 samples are located in the historical urbanized areas of the city (Fig. 2e). These samples with very low DO and high $\mathrm{NH}_{4}^{+}$recorded high scores for Factor 3 (Fig. 2d), indicating low direct recharge from precipitation 

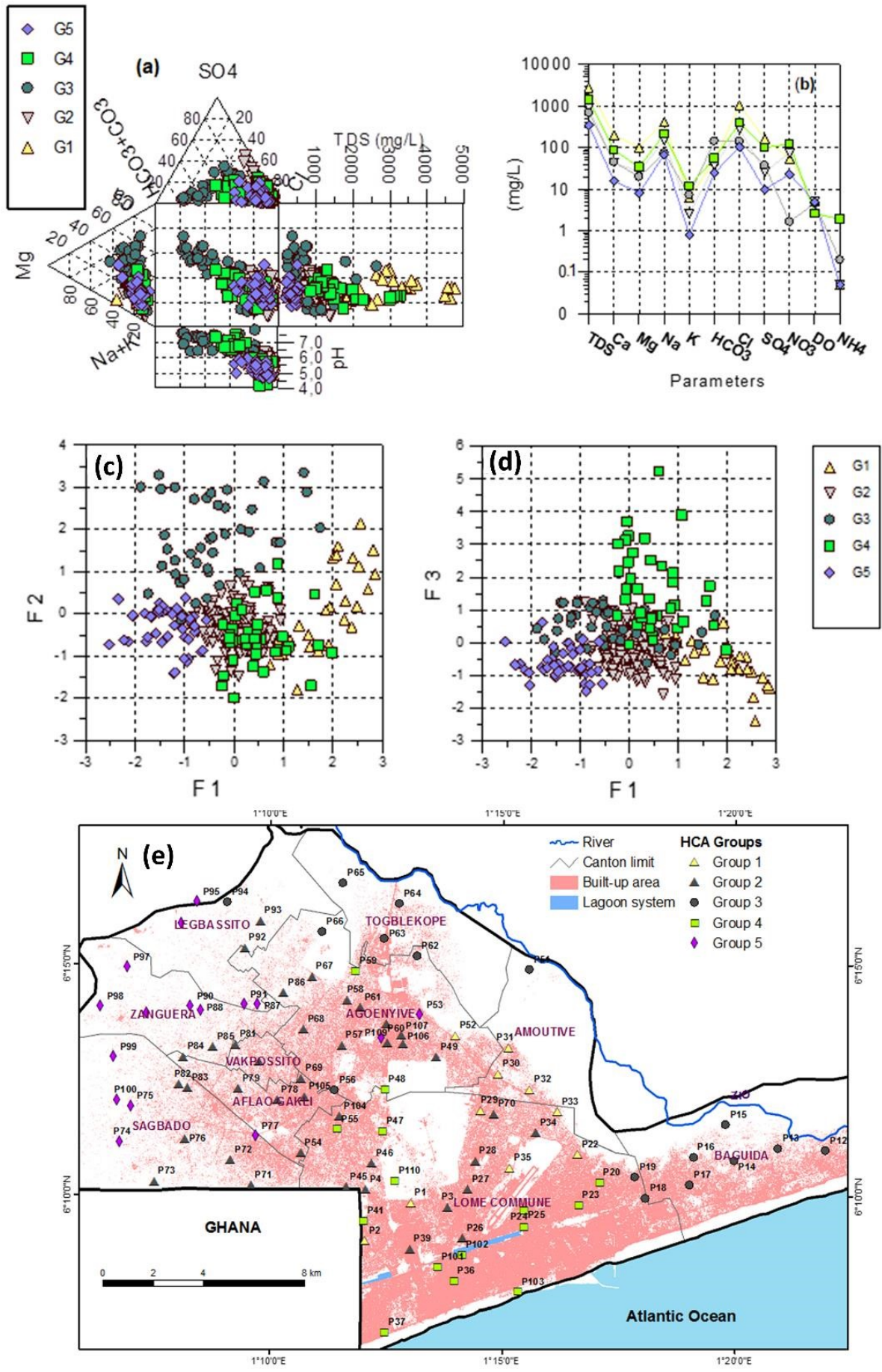

Figure 2. (a) Durov diagram of samples and (b) Schoeller diagram of the median chemical composition of each CHA group (b, c) Factorial scores for samples, (e) Spatial distribution of groups of samples. The built-up area is extracted from a SPOT-6 2015-12-08 satellite image (Copyright (C) AIRBUS Defence \& Space).

against an important infiltration of wastewaters from septic tanks and sewer and mixing with the polluted water from the lagoon system.

Low direct recharge may be explained by soil compactness due to urbanization and the high density of the popula- tion. Group 3 samples with the highest $\mathrm{pH}$ values and lowest $\mathrm{NO}_{3}^{-}$concentration display between $\mathrm{Na}-\mathrm{Cl}$ and $\mathrm{Ca}-\mathrm{Mg}-$ $\mathrm{HCO}_{3}$ water types end members (Fig. 2a). They recorded high scores for Factor 2, suggesting iron oxides and nitrate reduction by organic matter due to the lithology's detrital 
and sand clayey characteristics (Da Costa et al., 2013). Moreover, the localization of most of these samples in or near the flooding ground of Zio River (Fig. 2e) may suggest interactions with freshwater from Zio River and the upper Quaternary sediments along with denitrification processes. Group 1 samples recorded the highest salinity and present $\mathrm{Na}-\mathrm{Cl}$ and $\mathrm{Ca} / \mathrm{Mg}-\mathrm{Cl}$ water types. $\mathrm{Na}-\mathrm{Cl}$ water type with advanced hydrochemical evolution flow toward the central part of the alluvial plain of Zio River where $\mathrm{Na}^{+}$ions in water are exchanged with $\mathrm{Ca}^{2+}$ and $\mathrm{Mg}^{2+}$ fixed on sediments. Reverse cation exchange process were highlighted by the points displaying along the line of slope -1 in the diagram $\left(\mathrm{Na}^{+}-\mathrm{Cl}^{-}\right)$ vs $\left(\mathrm{Ca}^{2+}+\mathrm{Mg}^{2+}-\mathrm{HCO}_{3}^{-}-\mathrm{SO}_{4}^{2-}\right)$.

\section{Conclusions}

This study showed that shallow groundwater in the coastal city of Lome is predominantly acidic and $\mathrm{Na}-\mathrm{Cl}$ water types with mineralization ranging from soft waters to brackish ones. The PCA allowed identifying three main factors accounting for nearly $77 \%$ of the total variance in the water chemistry dataset. The first factor is salinity and results from marine aerosol, sea spray, sea intrusion, contamination from saline lagoon system, increasing salts dissolution along flow paths, and 140 anthropogenic contamination. The second factor related to redox conditions depends on lithology, recharge regime, and land use. The third factor, defined as indirect recharge from wastewaters, has revealed the impact of sanitation conditions on groundwater chemistry in the historic central part of the city. The hierarchical clusters analysis allows dividing samples into five main groups according to the hydrochemical evolution in the NW-SE direction of groundwater flow. In the Zio River alluvial plain, groundwater evolves toward $\mathrm{Na}-\mathrm{Cl} / \mathrm{HCO}_{3}$ and $\mathrm{Ca}-\mathrm{Mg}-\mathrm{HCO}_{3}$ water types due to mixing with fresh water from the surface and upper Quaternary sediments. These results appear helpful for understanding the evolution of the shallow groundwater chemistry in the coastal sedimentary basin of Togo.

Data availability. Data can be obtained by contacting the authors.

Author contributions. KVA, MDTG, LMB, and GDB conceived and designed the research; All authors contributed to research, activities, and paper writing

Competing interests. The contact author has declared that neither they nor their co-authors have any competing interests.

Disclaimer. Publisher's note: Copernicus Publications remains neutral with regard to jurisdictional claims in published maps and institutional affiliations.
Special issue statement. This article is part of the special issue "Hydrology of Large River Basins of Africa". It is a result of the 4th International Conference on the "Hydrology of the Great Rivers of Africa", Cotonou, Benin, 13-20 November 2021.

Acknowledgements. The Authors thank Sivapalan Young Scientists Travel Awards (SYSTA), IAHS, and the organizers of Friend Water's 4th International Conference on the Hydrology of the Great Rivers of Africa

Financial support. This research has been supported by the Delegation of the European Union to Togo and the Agency of Water and Sanitation for Africa, Office of Togo (grant no. DCINSAPVD/2013/308-062)

\section{References}

Alfa-Sika Mande, S.-L., Liu, M., Djaneye-Boundjou, G., Liu, F., Bawa, M. L., and Chen, H.: Nitrate in drinking water: A major polluting component of groundwater in gulf region aquifers, south of Togo, Int. J. Phys. Sci., 7, 144-152, https://doi.org/10.5897/ijps11.874, 2012.

Appelo, C. A. J. and Postma, D.: Geochemistry, groundwater and pollution, 2nd Edn., CRC Press, Taylor \& Francis Group, Boca Raton London New York, 2005.

Ayah, M., Grybos, M., Tampo, L., Bawa, L. M., Bril, H., and Djaneye-Boundjou, G.: Qualité et pollution des eaux d'un hydrosystème littoral tropical: cas du système lagunaire de Lomé, Togo, Eur. Sci. J., 11, 95-119, 2015.

BCR/DGSCN/MPRPDAT: Quatrième Recensement Général de la Population et de l'Habitat (RGPH4): Résultats définitifs, Document Gouvernemental, Ref. TGO_2010_PHC_v01_M, 57 pp., available at: https://catalog.ihsn.org//catalog/4097/ download/55189 (last access: 5 November 2021), 2011.

BRGM: Surveillance piézométrique et chimique des nappes du Bassin Sédimentaire Côtier du Togo. Synthèse des connaissances hydrogéologiques. Bureau de Recherces Géologiques et Minières, Republique Togolaise, Ministère des Travaux Publics, des Mines, de l'Energie, et des Ressources Hydrauliques, Direction de l'Hydraulique et de l'Energie, Orléans Cedex, Rapport BRGM Direction de l'Hydraulique et l'Energie/MTPMERH. CI04554, 1982

Cloutier, V., Lefebvre, R., Therrien, R., and Savard, M. M.: Multivariate statistical analysis of geochemical data as indicative of the hydrogeochemical evolution of groundwater in a sedimentary rock aquifer system, J. Hydrol., 353, 294-313, https://doi.org/10.1016/j.jhydrol.2008.02.015, 2008.

Da Costa, P. Y., Affaton, P., Salaj, J., Johnson, A. K. C., and Seddoh, K.: Biozonation des formations sédimentaires du bassin côtier du Togo (Afrique de l'Ouest), Rev. Ivoir Sci. Technol., 21-22, 4573, 2013.

Gnazou, M. D. T., Bawa, L. M., Banton, O., and Djanéyé-Boundjou, G.: Hydrogeochemical characterization of the coastal Paleocene aquifer of Togo (West Africa), Int. J. Water Resour. Environ. Eng., 3, 10-29, 2011. 
Gnazou, M. D. T., Sabi, B. E., Lavalade, J. L., Schwartz, J., Akakpo, W., and Tozo, A.: Multilayered aquifer modeling in the coastal sedimentary basin of Togo, J. Afr. Earth Sci., 125, 42-58, 2017.

Helstrup, T: Environmental isotopic and hydrochemical characteristics of groundwater from the Cretaceous-Eocene limestone aquifer in the Keta Basin, Ghana, and the Coastal Sedimentary Basin of Togo, PhD Thesis, University of Copenhagen, 2006.

Lapworth, D. J., Nkhuwa, D. C. W., Okotto-Okotto, J., Pedley, S., Stuart, M. E., Tijani, M. N., and Wright, J.: Urban groundwater quality in sub-Saharan Africa: current status and implications for water security and public health, Hydrogeol. J., 25, 1093-1116, https://doi.org/10.1007/s10040-016-1516-6, 2017.

Lee, J., Jang, C., Wang, S., Liang, C., and Liu, C.: Delineation of spatial redox zones using discriminant analysis and geochemical modelling in arsenic-affected alluvial aquifers, Hydrol. Process., 22, 3029-3041, https://doi.org/10.1002/hyp.6884, 2008.
Mande, S. A.-S., Liu, M., Djaneye-Boundjou, G., Liu, F., Bawa, M. L., and Chen, H.: Nitrate in drinking water: A major polluting component of groundwater in gulf region aquifers, south of Togo, Int. J. Phys. Sci., 7, 144-152, https://doi.org/10.5897/ijps11.874, 2012.

MPT-Togo: Cadre de gestion environnemental et social du projet WARCIP-Togo, Rapport Final, SECDE \& SOTED, 107 pp. + annexes, 2013.

Rodier, J., Legube, B., and Merlet, N.: L'analyse de l'eau, 9th Edn., Dunod, 2009.

Sylvain, J. P., Collart, J., Aregba, A., and Godonou, S.: Notice explicative de la carte géologique 1/500.0000 è du Togo, Direction Générale des Mines de la Géologie et du Bureau National de Recherches Minières Mémoire $\mathrm{N}^{\circ} 6,1986$. 